\title{
Binarność i sieć. Skracanie smyczy genetyczno-kulturowej w obliczu fizycznego zagrożenia dla zbiorowości społecznych
}

\author{
„Teksty z Ulicy. Zeszyt memetyczny” 2019, nr 20
}

Https://doi.org/10.31261/tzu.2019.20.03

\section{Streszczenie}

W artykule przedstawiono koncepcje skracania genetyczno-kulturowej smyczy pod wpływem wydarzeń stanowiących zagrożenie dla populacji. Ponieważ ocena realnego zagrożenia może być efektem oddziaływania mediów, wzmacnianie przekazu o takim zagrożeniu może prowadzić w rezultacie do upraszczania złożoności społeczno-kulturowego świata. Od kilku dziesięcioleci jako realne zagrożenie dla populacji Homo sapiens wskazuje się globalne ocieplenie. Autor na podstawie wieloletniej obserwacji kilku serwisów internetowych dotyczących tego zagadnienia przedstawia, w jaki sposób idee przenikają pomiędzy środowiskami popularyzatorów wiedzy o klimacie oraz ich przeciwników. Wiedza o tym, jakie są mechanizmy włączania/wyłączania sieci memów w sytuacji polaryzacji społecznej mogłaby się przyczynić do skuteczniejszej komunikacji marketingowej oraz efektywniejszego propagowania wiedzy poprzez środowiska popularyzatorów.

\section{Słowa klucze:}

polaryzacja społeczna, upraszczanie złożoności, replikacja memów, reguły epigenetyczne

\section{Binarity and network. Shortening the genetic-cultural leash in the face of the physical threat for the social collectives}

\section{Summary}

The article presents the concepts of shortening the genetic-cultural leash under the influence of events posing a threat for the population. Since the assessment of the real threat may be the effect of media influence, strengthening the message of such a threat may lead as a result to simplifying the complexity of the socio-cultural world. Shortening the leash may consist in partial rejection of products of strictly cultural evolution, and as a consequence of cultural diversity, in favor of more primitive patterns of thinking and acting. The consequence of this is self-perpetuating social polarization, which can sometimes lead to the feedback in the form of increasing the threat to the population. At the same time, defense mechanisms negating the threat may be revealed, and thus neutralize the emotions associated with it. In the event that the threat is real, the parties to the dispute may authenticate their own message, using arguments of oppo- 
nents as well. At the memetic level, this may mean the relative closing of the memplexes and the adoption of "foreign" memes using mechanisms of regulation, manipulation of the status of a given idea in the network of meanings through meta-memes.

For several decades, global warming has been indicated as a real threat to the population of Homo sapiens. On the basis of long-term observation of several websites, the author presents how ideas penetrate between communities of promoters of knowledge about the climate and their opponents.

Keywords:

simplifying the complexity, social polarization, replication of memes, epigenetic rules

\section{Kulturowe replikatory w perspektywie sieciowej}

James Watson, współodkrywca struktury DNA, wspominał, że do jej odkrycia przyczyniło się m.in. intuicyjne myślenie o powszechnie występującej w świecie biologicznym parzystości, symetryczności ${ }^{1}$. Binarność podwójnej helisy nie musi jednak przekładać się na częste występowanie parzystych alleli genów (dominujących i recesywnych), symetryczności ciał, bądź dwóch rodzajów płci, choć taki porządek rzeczy jest w naturze dość powszechny.

Zwrócenie uwagi na parzystość nie było też pewnie konieczne, aby odkryć, w jaki sposób replikują się geny w wytwarzanych przez siebie organizmach. O ile w odniesieniu do replikacji genów intuicja ta była trafna, to w przypadku „drugiego replikatora”, jakim jest mem, poszukiwanie struktur odpowiedzialnych za replikowanie się informacji kulturowej należałoby rozpocząć od analogii sieciowej. Jeżeli bowiem mem jako najmniejsza jednostka informacji kulturowej podlegająca kopiowaniu i generująca samo kopiowanie znajduje się w mózgu, to jest strukturą składającą się z neuronów, które z kolei łączą się w różnego typu sieci. Zdaniem neurologów, anatomia tych komórek wymusza wytwarzanie kaskadowych powiązań o strukturze drzewa. Mimo braku jednoznacznych dowodów na to, że łączenie się neuronów w sieci przekłada się na dendryczny charakter wytworów naszych mózgów, próba zastosowania analogii sieciowej do namysłu nad kulturą - jednego z efektów działań myśli - nie wydaje się bezpodstawna. Jak piszą Ian Stewart i Jack Cohen, przybliżając pojęcie eksteligencji jako kulturowego, ponadorganicznego odpowiednika inteligencji, ,język rozbudowuje się [...] w procesie, w którym każde słowo zostaje obficie okraszone rozmaitymi dziwnymi skojarzeniami. Słowa nie sa biernymi, abstrakcyjnymi symbolami: kapią z nich znaczenia, a eksteligencja dobrze to sobie uświadamia, nawet jeśli poszczególne jednostki o tym zapominaja”². Tworzenie się sieci powiązań między słowami i ich znaczeniami może podlegać podobnym regułom, jak tworzenie się powiązań między neuronami.

Sieciową naturę kultury wiązać można z sieciami relacji społecznych.

\footnotetext{
Zob. J. Watson, Podwójna helisa, przel. W. Zagórski, Warszawa 1996.

2 I. Stewart, J. Cohen, Wytwory rzeczywistości. Ewolucja umystu ciekawego, przeł. W. StępieńRudzka, Warszawa 2003, s. 296.
} 
Robin Dunbar zwrócił uwagę, że w przypadku naczelnych występują określone wielkości stad (grup) osobników zależnie od gatunku, co koreluje ze stosunkiem masy mózgu do masy ciała przedstawiciela danego gatunku oraz z proporcja wielkości kory nowej do całego mózguª Kora nowa to nowa część mózgu, charakterystyczna dla ssaków, a szczególnie rozbudowana u naczelnych. Zależność ta związana jest z tym, że funkcjonowanie w dużych społecznościach i rozwiązywanie wielu dylematów dotyczących współpracy, budowania koalicji oraz pamiętanie zachowań innych osobników wymaga dużych mocy obliczeniowych. Większe możliwości poznawcze mózgu sprzyjają bardziej złożonym zachowaniom, co z kolei przekłada się na wielkość grup (społeczności) ${ }^{4}$. Ponadto społeczności nie są jednolitymi bytami społecznymi, a posiadają swoją wewnętrzną strukturę. Chociaż gatunek Homo sapiens wytwarza wiele różnych typów struktur organizacyjnych, wskazuje się na pewną prawidłowość w wielkości struktur podstawowych. W przypadku zbiorowości łowców-zbieraczy opisuje się powiązania strukturalne w postaci „zasady trzech”, odnoszącej się do skalowalności sieci społecznych relacji. Najbliższe relacje budowane są w obrębie grup osobistych liczących ok. 4-5 osób. Potrojenie tej liczby występuje w przypadku grup zbierackich (grup wsparcia). Około 50 osób liczą nocne grupy obozowe, 150 osób to liczba Dunbara określająca charakterystyczną dla gatunku wielkość podstawowej społeczności tworzona przez bliższych znajomych. Dalsi znajomi, z którymi nawiązuje się kontakty handlowe i matrymonialne to zbiorowość licząca pół tysiąca jednostek, kolejne zaś potrojenie wyznacza zakres plemienia posługującego się wspólnym językiem (etnolektem) ${ }^{5}$. Język mógł zaś rozwinąć się właśnie ze względu na zacieśnianie więzi między jednostkami. Dawał on większe możliwości wiązania się z innymi niż służące do tego samego iskanie, stosowane przez naczelne. Jednorazowo można rozmawiać z większą liczbą osób niż w przypadku iskania, a tym samym budować większe koalicje poświęcając na to mniej czasu ${ }^{6}$. Także wytwarzanie narzędzi kamiennych sprzyjało rozwijaniu funkcji poznawczych i planowania, a przekazywanie informacji werbalnie mogło być skuteczniejsze niż naśladowanie czynności manualnych przy modelowaniu narzędzi ${ }^{7}$. Narzędzia kamienne powstawały przed pojawieniem się aparatu mowy, bo już 2 miliony lat temu (inne najpewniej wcześniej, ale ze względu na rodzaj materiału nie dotrwały do współczesności), a skokowy wzrost wielkości mózgów dokonał się znacznie później - w czasie, gdy wzory wytwarzania narzędzi stały się bardziej skomplikowane, co pewnie wymagało wejścia na abstrakcyjny poziom myślenia i większą złożoność planowania.

Mózg, jako miejsce przechowywania informacji z miliardami neuronów i o kilka rzędów wielkości większą liczbą połączeń między nimi, jest na tyle skomplikowaną

\footnotetext{
R. Dunbar, Pchty, plotki, a ewolucja jezyka, przeł. T. Pańkowski, Kraków 2017.

Tamże.

C. Gamble, J. Gowlett, R. Dunbar, Potega mózgu. Jak ewolucja życia spotecznego ksztattowata ludzki umyst, przeł. R. Kosarzycki, Kraków 2017, s. 54-56.

Tamże, s. 212-213.

Zob. D. Stout, Neurobiologia epoki kamienia, „Świat Nauki” 2016, nr 5, s. 22-29.
} 
strukturą, że podejmowanie badań nad jego właściwościami może co najmniej onieśmielać. Już sama percepcja wzrokowa wiąże się z setkami połączeń między kilkudziesięcioma obszarami mózgu, a nie do końca wiadomo, za co odpowiadaja poszczególne połączenia ${ }^{8}$. Niemniej już w latach 40. XX wieku Alan Turing przewidywał, że maszyny cyfrowe mogłyby podobnie jak mózgi doskonalić się poprzez uczenie, analogicznie do organizmów nabywających nowych cech adaptacyjnych w procesie ewolucji ${ }^{9}$. Nieznajomość dokładnego działania mózgu bądź kodu DNA nie oznacza, że fragmentaryczna wiedza nie może być przydatna. Szczególnie jeśli jest to wiedza o elementarnych zasadach działania maszyny, niezależnie od tego, czy jest ona wytworzona przez dobór naturalny, czy jest efektem zaprogramowania przez człowieka. Fascynacja skomplikowaną strukturą mózgu prowadziła nie tylko do tworzenia wizji przyszłych maszyn cyfrowych, ale znalazła zastosowanie w modelowaniu rzeczywistości z wykorzystaniem tzw. sieci neuronowych opartych na „sztucznych neuronach”. Analogie między złożonością sieci neuronów a relacjami ekonomicznymi zauważane są w badaniach nad zachowaniami graczy na giełdzie $^{10}$. Inne analogie pojawiały się w kulturoznawstwie, np. w koncepcji struktur kłączastych kultury, które rozumiano jako chaotyczne sieci. Przeciwstawia się im uporządkowane struktury drzewa. Schematy powiązań (gałęzie) struktur drzewiastych obrazować może porządek biurokratyczny bądź każdy przejrzysty system, w którym istnieją elementy podstawowe (główne) i pochodne (poboczne). Pojęcie struktur kłączastych z kolei zaadaptowane zostało do analizowania cyberprzestrzeni, a przede wszystkim tworzonych oddolnie nowych mediów ${ }^{11}$. W końcu cyberprzestrzeń to emanacja współczesnego społeczeństwa, określanego jako sieciowe, funkcjonującego w środowisku stworzonym przez człowieka, w środowisku stricte kulturowym.

Wobec powyższego można zadać pytanie, w jakim stopniu należałoby ujmować podstawowe elementy replikacji kulturowej - memy w kategoriach struktury sieciowej. Można je traktować jako węzły sieci w naszych umysłach, a same sieci jako mempleksy (kompleksy memów), przy czym memy podobnie jak geny są tu traktowane jako jednostki informacji. W odróżnieniu od genów nie sa jednak zapisane w kodzie DNA, a na materialnej matrycy tworzonej przez neurony ${ }^{12}$. Skalowalność, jako właściwość sieci, pozwala z kolei na tworzenie sieci mempleksów. Każdy mempleks może być więc zarówno siecią memów, jak i siecią mempleksów, jeżeli taka sieć będzie ekspandować. Pod koniec lat 60. XX wieku pojawiły się hipotezy zakładające, że poszczególne neurony lub ich grupy są odpowiedzialne

\footnotetext{
8 V.S. Ramachandran, Neronauka o podstawach cztowieczeństwa, przel. A. i M. Binderowie, E, Józefowicz, Warszawa 2012, s. 78-79.

9 P. Coveney, R. Highfield, Granice złożoności, przeł. P. Amsterdamski, Warszawa 1997, s. 91-92.

10 C. Zimmer, Sto bilionów potaczeń, „Świat Nauki” 2011, nr 2, s. 50-55.

11 P. Celiński, Interfejsy. Cyfrowe technologie w komunikowaniu, Wrocław 2010, s. 185-186.

12 W. Borkowski, Memy - reinterpretacja systemowa, „Teksty z Ulicy. Zeszyt Memetyczny” 2016, nr 17, s. 48-49.
} 
za zapamiętywanie poszczególnych obiektów ${ }^{13}$. Przez długi czas hipoteza ta była traktowana jako spekulacja. Obecne badania potwierdzają, że nie tylko poszczególne obszary mózgu odpowiadają za rozpoznawanie konkretnych obiektów, ale konfiguracje sieci składających się z kilkudziesięciu komórek odpowiadają za rozpoznawanie konkretnych twarzy. W procesie percepcji twarzy uaktywniaja się w różnym nasileniu komórki nerwowe umieszczone na kilku tzw. plamkach, reagując na kilkadziesiąt zmiennych (kształt, jaśniejsze i ciemniejsze obszary na powierzchni twarzy itp.), jednak tylko kilkadziesiąt neuronów w różnych konfiguracjach uaktywnia się w zależności od tego, z jaką twarzą ma do czynienia mózg człowieka ${ }^{14}$. Funkcjonalność większości neuronów w tych częściach mózgu jest efektem działania doboru naturalnego. Jesteśmy ewolucyjnie wytresowani do rozpoznawania twarzy. Rozpoznawanie konkretnej twarzy to jednak kwestia treningu indywidualnego i osobniczego wiązania tych sieci neuronów z innymi, które odpowiedzialne są za pamięć dotyczącą poszczególnych osób.

Chociaż mózg człowieka bardzo dobrze radzi sobie z rozpoznawaniem twarzy, to jednak obrazy twarzy nie są obiektami, które łatwo poddają się replikowaniu. Jak wskazują doświadczenia kryminologów, stworzenie portretu pamięciowego wcale nie jest proste. Inaczej to wygląda w przypadku słów. Replikują się one bardzo szybko, w szczególności w początkowych etapach życia człowieka, od chwili, gdy młody osobnik naszego gatunku potrafi już je powtarzać. Daniel Dennett stwierdza, że słowa są bardzo dobrymi kandydatami na memy, podobnie jak inne mogące dać się „ucyfrowić” jednostki kulturowego przekazu: zapisywane za pomocą nut dźwięki, replikujące się niezależnie od tego, czy są one też zapisywane poza mózgiem. Dotyczy to wszelkich treści kulturowych, które mogą podlegać kodyfikacji ${ }^{15}$. Chociaż nie określono, jak dokładnie są te treści zapisywane na poziomie sieci neuronów, to możliwe jest już zlokalizowanie niewielkich obszarów mózgu, które uaktywniają się w momencie usłyszenia, wypowiedzenia słowa, a także wówczas gdy się o danym słowie pomyśli. Lokalizacje poszczególnych słów są podobne u różnych osób ${ }^{16}$.

\section{Sieciowa struktura komunikacji językowej}

Na poziomie ekspresji treści kulturowych, a więc uzewnętrznienia, przekazu oraz wspólnego podzielania w kulturze, daje się je ujmować w kategoriach sieci powiązań. Ekspresja słowa może dokonywać się jednak na wiele różnych sposobów. Zarówno znaczenie danego słowa może się zmieniać w zależności od kontekstu (powiązania z innymi słowami), jak i brzmienie oraz jego wizualna manifestacja w tekście. Ta wieloraka ekspresja słowa jako memu wskazuje, że na poziomie

13 Tamże, s. 49.

14 D.Y. Tsao, Kod twarzy, „Świat Nauki” 2019, nr 3.

15 D. Dennett, Od bakterii do Bacha. O ewolucji umystów, przeł. K. Bielecka i M. Miłkowski, Kraków 2017, s. 297-306.

16 P. Łaszczyca, Memy w pamięci: jak wyśledzić memy z mózgu, „Teksty z Ulicy. Zeszyt Memetyczny" 2017, nr 18, s. 29. 
neuronów są to złożone sieci powiązań. Najprawdopodobniej jednak są one mniej trwałe niż stabilne struktury odpowiadające za rozpoznawanie twarzy. Założyć można, że nietrwałość i plastyczność sieci powiązań między neuronami odpowiedzialnej za przyjmowanie treści kulturowych (nabywanie ich na drodze socjalizacji), jest skutkiem podporządkowania utrwalonym ewolucyjnie sieciom w mózgu. Utrwalone biologicznie struktury mają pierwszeństwo w działaniu przed strukturami wytworzonymi u osobnika w czasie jego (kulturowego) życia.

Szukając uzasadnień dla ukazywania sieciowej natury kulturowego replikatora, można też wskazać na procesy ewolucji języka. Choć są różne propozycje wskazania głównych przyczyn jego wytworzenia u rodzaju Homo, złożony język pozwalał na tworzenie rozbudowanych opowieści, mitów i wplatanie w nie „nieobecnych” członków społeczności, także zmarłych. To z kolei odnosi się do wchodzenia na wyższe poziomy intencjonalności. Na pierwszym poziomie intencjonalności jednostka jest samoświadoma, na drugim jest świadoma cudzego umysłu, na trzecim uświadamia sobie, że osobniki mające umysły także są świadome cudzego umysłu itd. Zakłada się, że jedynie przedstawiciele gatunku Homo sapiens weszli na piąty poziom intencjonalności, a część osób osiąga poziom szósty ${ }^{17}$. Im wyższy poziom, tym bardziej rozbudowane są mechanizmy pozwalające na podejmowanie decyzji, symulowanie interakcji z innymi osobami i przewidywanie. Pozwala to także zarówno na wytwarzanie różnych sposobów oszukiwania innych w konkurencji o zasoby, jak i na wykrywanie oszustów. Postępujący „wyścig zbrojeń” między oszustami i osobami wykrywającymi oszustwa prowadzi do wytwarzania mniej lub bardziej restrykcyjnych reguł kulturowych, odpowiadających im dewiacji społecznych, inflacji prawa, ale jednocześnie służy wytwarzającym te mechanizmy ludzkim populacjom. Badania potwierdzają, że u osób swobodniej operujących na wyższych poziomach intencjonalności bardziej rozbudowana jest kora oczodołowo-czołowa, której neurony aktywowane są przy rozwiązywaniu problemów dotyczących cudzych intencji ${ }^{18}$.

Z sieciowością wiązać można też właściwość języka, jaką jest stosowanie metafor i analogii, które są prawdopodobnie specyficzne tylko dla ludzkiej komunikacji ${ }^{19}$. Odnoszenie pojęć do zupełnie innego porządku znaczeniowego można rozumieć jako splatanie wielu różnych nici syntaktycznych. Stabilizacja znaczeń następować może dopiero poprzez konwencjonalne ustalenie tego, co początkowo było metaforyczne i przez to wieloznaczne. Edmund Leach rozumiał to jako transformację symbolu znajdującego się w domenie metafory w znak odpowiadający porządkowi metonimii ${ }^{20}$. Konwencjonalnie ustala się sieci znaczeń, co na poziomie neuronów znów oznacza utrwalanie sieci powiązań, a więc

17 C. Gamble, J. Gowlett, R. Dunbar, Potęga mózgu..., s. 216-219.

$18 \quad$ R. Dunbar, Cztowiek..., s. 59.

19 Vilayanur S. Ramachandran zauważa, że nawet jeśli niektóre komunikaty stosowane przez małpy można uznać za metafory, to są one tylko prostymi wyrażeniami w stosunku do metafor stosowanych w poezji: V.S. Ramachandran, Neuronauka..., s. 182-183.

20 K. Leach, Kultura i komunikowanie, przeł. M. Buchowski, Warszawa 2010, s. 17-22, 27. 
utrwalanie struktur memów. To pozwala zaś na osiągnięcie wierności kopiowania informacji. Aby dany replikator mógł być skuteczny, poza wiernością powinien też charakteryzować się łatwością kopiowania, ograniczoną zmiennością i względną stabilnością formy ${ }^{21}$. Stabilna forma informacji jest łatwiejsza do wiernego skopiowania do innego umysłu. Im bardziej nasila się proces konwencjonalnego rozpoznawania symbolu (poprzez upowszechnienie takiego samego rozumienia i wyrażania), tym większe są szanse na przetrwanie memu (memów) odpowiedzialnego za replikację. Relacje między symbolami i znakami można odnieść do koncepcji $e$-memów i $i$-memów Adama McNamary. W koncepcji tej memy zinternalizowane przez jednostkę to $i$-memy, a e-memy to memy eksternalizowane. Dany mem, choć jest najmniejszą jednostką informacji, przekazywany jest z mózgu do mózgu w częściach. Przekazywane są fragmenty $i$-memów poprzez odpowiednią sekwencję e-memów. Aby mem .mógł być zinternalizowany, musi wystąpić sekwencja eksternalizacji jego części składowych, szczególnie jeśli dotyczy on mniej lub bardziej złożonej idei (np. „droga z pracy”, „łyżka do butów”)22. Proste memy rozprzestrzeniają się natomiast bez dzielenia się na części. Podobnie w przypadku metafor rozumienie (internalizacja) wymaga przyjęcia kilku informacji (memów) z różnych porządków znaczeniowych - znaki mogą być przekazywane poprzez odniesienie ich do jednego porządku rzeczywistości, a więc wystarczy jednorazowy kontakt z danym znakiem (z obiektem i przypisywanym mu znaczeniem). Zakłada się, że metafory są konieczne do językowego komunikowania się. Umożliwiają one dostęp do budowanych jako sieci neuronów ram asocjacyjnych, które z kolei sa częściami składowymi szerszych narracji ${ }^{23}$. W ujęciu memetycznym można byłoby powiedzieć, że znaki są utrwalonymi wyraźnie powiązaniami neuronowymi odpowiedzialnymi za eksternalizację $e$-memów, metafory bądź rozbudowane struktury syntaktyczne są sieciami tworzącymi $i$-memy, ramy asocjacyjne są podstawowymi mempleksami, a narracje są rozbudowanymi mempleksami drugiego poziomu.

Warto zwrócić uwagę, że wytwarzanie i przekazywanie nowych znaczeń wzbogaca kulturową różnorodność, jednocześnie prowadząc do możliwych zaburzeń w wierności przekazu. Szczególnie jeśli dotyczy to przekazywania znaczeń danego symbolu. Im bardziej kultura obfituje w metafory, tym bardziej zwiększa się jej złożoność, rozrastają się powiązania między znaczeniami. Powoduje to wzrost liczby interpretacji i niepewność tego, czy rozumie się przekaz kierowany przez nadawcę.

\section{Redukowanie kulturowej złożoności jako skracanie smyczy genetyczno-kulturowej}

Stewart i Cohen przedstawiając koncepcję kontekstualnego podejścia do rzeczywistości jako odpowiedź na zarzut niemożności wyjaśniania redukcjonistycz-

$21 \quad$ P. Łaszczyca, Memy w pamięci..., s. 19.

22 Por. W. Borkowski, Memy - reinterpretacja systemowa .., s. 51-53.

23 M. Castells, Wtadza komunikacji, przeł. J. Jedliński, P. Tomanek, Warszawa 2013, s.149. 
nego, podkreślali, że użyteczność redukcjonizmu w nauce występuje wówczas, gdy jeden poziom rzeczywistości analizuje się, odnosząc go do bezpośrednio niższego poziomu. Przykładem może być wyjaśnianie zachowań organizmów biologicznych poprzez odniesienie do reguł epigenetycznych w mózgu, które z kolei wytwarzane są na poziomie genetycznym. Wyjaśnianie na poziomie reagowania molekuł, które prowadzą do wytworzenia DNA, byłoby tu zbyt daleko posuniętym redukcjonizmem. Nie oznacza to, że w ogóle nie można byłoby w ten sposób opisywać zjawisk, ale to ograniczenie do wyjaśniania w obrębie dwóch powiązanych poziomów rzeczywistości wynika ich zdaniem z tego, że ludzkie mózgi nie radzą sobie z operowaniem złożonościami jako takimi ${ }^{24}$. Nie dotyczy to tylko obejmowania umysłem wytwarzania się wielu kolejnych, emergentnych wobec siebie poziomów, ale również postrzegania sieci złożoności na jednym poziomie (w jednej przestrzeni fazowej). Złożoność redukujemy już na poziomie percepcji - do naszej świadomości dociera jedynie niewielki fragment informacji z tych, które przez siatkówkę oka przedostają się do mózgu. Ponieważ umysł nie jest wystarczającym narzędziem do wyjaśniania układów złożonych, dla postępów w nauce koniecznym stało się użycie maszyn cyfrowych, mogących podawać wyniki skomplikowanych obliczeń i pozwalać na opisywanie procesów zachodzących w otaczającym nas świecie. Jeszcze w latach 70. XX wieku matematycy, sceptycznie nastawieni wobec „empirycznego” dowodzenia twierdzeń, zarzucali, że wykorzystanie komputerów nie jest właściwym podejściem, ponieważ dowodzenie „dzieje się” poza umysłem matematyka. Skuteczność działania maszyn cyfrowych przekonała ich do zrewidowania własnego stanowiska ${ }^{25}$. W naukach społecznych nadal jednak zdaje się przeważać podejście polegające na ucieczce od złożoności w upraszczanie, operuje się prostymi typami idealnymi. Im bardziej złożone jest społeczeństwo, tym bardziej takie praktykowanie nauki prowadzi do niemożności wyjaśniania i przewidywania. Dodatkowo zakłada się, że powinno się analizować sposoby rozumienia rzeczywistości społecznej przez funkcjonujących w niej członków zbiorowości, aby móc wyjaśniać, dlaczego zachowują się oni w taki, a nie inny sposób. Jak zauważa Dennett, memetyka mogłaby być nauką, która pozwala na opisywanie rozprzestrzeniania się nowych memów (innowacji) bez konieczności odwoływania się do podmiotowego działania (intencjonalności, świadomości, rozumienia), co mogłoby skuteczniej wyjaśniać wzory takiego propagowania memów w kulturze ${ }^{26}$.

Mając świadomość własnych tendencji do upraszczania złożonej rzeczywistości, zastanawiać można się np. nad tym, czy prace antropologów funkcjonujących w paradygmacie strukturalnym trafnie analizowały badaną rzeczywistość, czy też przedstawiały artefakty, konstrukty teoretyczne ukształtowane w umysłach badaczy. Przykładem mogą być spostrzeżenia Claude’a Lévi-Straussa dotyczące

24 I. Stewart, J. Cohen, Wytwory ..., s. 65.

25 P. Coveney, R. Highfield, Granice ztożoności..., s. 68-69.

26 D. Dennett, Od bakterii..., s. 316-317. 
powszechności struktur binarnych i trójdzielnych w kulturach pierwotnych. Miał on jednak świadomość tego, że rzeczywiste struktury charakteryzują się większą złożonością. Pisał m.in., że „badanie tzw. organizacji dualistycznych objawia tyle anomalii i sprzeczności, że należałoby [...] traktować pozorne formy dualizmu jako powierzchniowe zniekształcenia struktur, których prawdziwa natura jest inna i o wiele bardziej złożona" ${ }^{27}$. Dualistyczne struktury są ponadto dość dobrze w warstwie językowej ludów, które te struktury wytwarzają. Nawet jeśli jest to tylko powierzchowna emanacja głębiej osadzonych relacji, to na poziomie świadomości mogą one pozwalać na umysłowe pojmowanie własnej rzeczywistości kulturowej przez tych ludzi. Z kolei anomalie mogą być efektem wzrostu złożoności, który kulturowo jest redukowany dzięki regułom istniejącym w systemie społecznym. Co więcej, wzrost złożoności na poziomie języka, nawet jeśli brać pod uwagę przyrost słów odnoszących się do jakiegoś aspektu rzeczywistości, może ewoluować w bardzo podobny sposób. W przypadku terminów określających kolory najpierw pojawiaja się te, które pozwalają na rozróżnianie ciemnych i jasnych obiektów, potem pojawiają się w kolejności słowa określające kolor czerwony, zielony i żółty, niebieski i w dalszej kolejności brązowy ${ }^{28}$. Ujmując tę kwestię inaczej, można powiedzieć, że społeczności potrzebują jednoznacznych określeń dotyczących ich rzeczywistości, aby sprawnie się komunikować, co w przypadku pojawiania się wieloznaczności i obrastania znaczeniami przez symbole może uruchamiać mechanizmy prowadzące do redukowania nadmiernej złożoności. Im większe są sieci społeczne, a dokładniej im bardziej postępuje łączenie się tych sieci, tym większy może być zasób znaczeń dla jednostek. Cyklicznie moga pojawiać się zjawiska prowadzące do redukowania różnorodności kulturowej i odrzucania „obcych memów”, a zarazem do polaryzacji społecznej, coraz wyraźniejszego podziału na swoich i obcych. Nie oznacza to utraty zdolności posługiwania się nazwami podstawowych kolorów, których słowniki we współczesnych kulturach są mocno rozbudowane. Kolory moga być istotne dla rozróżniania szans i zagrożeń dla jednostki, ale pojęcia odnoszące się do struktur społecznych i reguł działania w społecznościach mogą być upraszczane w przypadku silnych antagonizmów. Eksperyment więzienny Philipa Zimbardo wyraźnie wskazuje, że w sytuacji zagrożenia jednostki mogą odrzucać przyjmowane na drodze socjalizacji reguły współżycia społecznego.

\section{Polaryzacja społeczna - następstwo nieradzenia sobie z kulturową złożonością}

Binarność jest dobrze widoczna nie tylko w przypadku zagrożenia dla egzystencji, ale też w określaniu atrakcyjności, co przekłada się na myślenie estetyczne. Symetryczne ciała i symetryczne twarze są świadectwem zdrowia, a dokładniej braku pasożytów zniekształcających te ciała. To z kolei jest efektem ukształtowanych

\footnotetext{
27 C. Lévi-Strauss, Antropologia strukturalna, przeł. K. Pomian, Warszawa 2000, s. 145.

28 E.O. Wilson, Konsiliencja. Jedność wiedzy, przeł. J. Mikos, Poznań 2002, s. 246.
} 
ewolucyjnie reguł epigenetycznych w ludzkim mózgu, które wspomagają dobór płciowy ${ }^{29}$. Wybór partnera bądź partnerki pozbawionej pasożytów daje większe szanse na przeżycie spłodzonych dzieci. Reguły epigenetyczne Edward Wilson opisywał jako genetycznie dziedziczone szlaki połączeń między neuronami, które uaktywniane są poprzez ekspozycję na reguły kulturowe, jak np. wzmacnianie strachu przed wężami przez eksponowanie ich symboliki i nadawanie im negatywnych znaczeń. Oznacza to, że warstwa symboliczna jest zależna od uwarunkowań biologicznych (genetycznych). Zależność tę Wilson ujmował pojęciem smyczy genetyczno-kulturowej. Ponieważ znaczna część węży jest jadowita, wytworzenie danej reguły, która będzie kulturowo wzmacniana, pozwala na większe szanse przeżycia i przekazania jej na drodze genetycznej kolejnym pokoleniom ${ }^{30}$. Odchodzenie od danych reguł skutkuje negatywnymi konsekwencjami dla jednostek i tworzonych przez nie zbiorowości. W nowoczesnych społeczeństwach te dawne lęki przed jadowitymi stworzeniami przestały mieć już biologiczne znaczenie, jednak istnienie np. arachnofobii świadczy o tym, że biologia nadal trzyma kulturę na smyczy. Chociaż nie spotykamy na co dzień zagrażających nam drapieżników, w popkulturze nadal są one popularne, a horrory filmowe z cyklu Obcy (wywołujące lęk zarówno przed pasożytami, jak i drapieżnikami) nadal są produkowane ${ }^{31}$. Symetria nie jest oczywiście jedynym czynnikiem pozwalającym na określanie atrakcyjności. Ramachandran wskazuje, że może ona działać wówczas, gdy idzie w parze w odrzucaniu zbiegów okoliczności. Jeśli symetria dotyczy porządku, który traktujemy jako nienaturalny, zbyt podejrzany, może być przez nas odrzucany ${ }^{32}$.

Jeżeli biologiczne struktury cechują się tym, że często w nich występuje symetria, parzystość bądź inne aspekty binarności, a ewolucyjną adaptacją jest reagowanie na tę binarność lub jej brak, to wraz z rozwojem społecznym, większym wpływem człowieka na kształtowane przez niego środowisko i przez to luźniejsza smyczą genetyczno-kulturową, powinna też spadać skłonność do takiego reagowania. Nie oznacza to, że sieciowość należy wiązać stricte z kulturą, a binarność z biologią. W końcu złożoność biologicznych ekosystemów trudno byłoby rozpatrywać w taki sposób, w jaki antropolodzy analizowali przestrzenne układy plemiennych wiosek. Niemniej polaryzację społeczną można ujmować w kategoriach odwrotu od sieciowej złożoności w kierunku dwuwartościowego świata społecznego. Takie upraszczanie można właśnie wiązać z nieradzeniem sobie ze zbyt dużą złożonością. Émile Durkheim, a później Robert K. Merton opisywali stan anomii jako sytuację,

29 V.S. Ramachandran, Neronauka..., s. 254; por. D. Danel, B. Pawłowski, Biologiczne znaczenie atrakcyjności twarzy, W: Biologia atrakcyjności cztowieka, red. B. Pawłowski, Warszawa 2009, s. 174-175.

30 Tamże, s. 192-193.

31 Na cykl filmów o Obcych jako wykorzystujących wiele motywów odnoszących się do ukształtowanych ewolucyjnie lęków wskazują Tomasz Szlendak i Tomasz Kozłowski w psychoewolucyjnej analizie twórczości kinematograficznej: T. Szlendak, T. Kozłowski, Naga matpa przed telewizorem. Popkultura w świetle psychologii ewolucyjnej, Warszawa 2008, s. 262-263.

32 V.S. Ramachandran, Neronauka..., s. 251-252. 
w której załamuje się porządek społeczny pod wpływem pojawiania się nowych reguł, a więc w wyniku kulturowych innowacji ${ }^{33}$. Załamywanie to opisywano jako problem związany z podejmowaniem decyzji. Członkowie zbiorowości tracili bowiem pewność czy obowiązujące są poprzednie, czy też obecne reguły. Konsekwencją tego mogło być odrzucanie starych lub nowych reguł, ale też większa skłonność do omijania jakichkolwiek reguł przyjętych w danej zbiorowości. Pojawianie się nowych elementów kulturowych powoduje większą złożoność społecznego świata, czego rezultatem jest uruchamianie mechanizmów prowadzących do jej redukowania. W takim przypadku byłaby to reakcja na zagrożenie bezpieczeństwa ontologicznego. Jednostki przestają być pewne co do rzeczywistości, w której funkcjonują. Sytuacja ta jest analogiczna do wyłączania reguł w eksperymencie więziennym przeprowadzonym przez Zimbardo, co w konsekwencji wyzwalało stosowanie przemocy. Nierzadko takie sytuacje określa się mianem zezwierzęcenia. Należałoby jednak nadmienić, że wyłączane są też te reguły, które nie są ukształtowane dzięki kulturze, lecz w wyniku ewolucji ssaków jako zwierząt społecznych. Frans de Waal argumentuje, że także u spokrewnionych z ludźmi szympansów i bonobo występują hamulce moralne, przy czym u tych drugich są rzadziej wyłączane niż u ludzi ${ }^{34}$.

Gdy w zbiorowościach ludzkich pojawia się polaryzacja, prowadzi przede wszystkim do antagonizmów, a często do eskalacji konfliktów, czemu towarzyszy także wzrost spójności wewnętrznej grup (zbiorowości) będących ze sobą w konflikcie. Powoduje to zamykanie się na relacje z obcymi i kulturową specjację, jeśli podziały się utrwalają, lecz również tym samym wykształca się kulturowa różnorodność w populacji globalnej. Możliwości styku z odmiennymi kulturami z kolei prowadzą do wzajemnego przenikania treści kulturowych, a więc memetycznej ekspansji. Następnie moga pojawiać się kolejne konflikty powodujące znów zamykanie się kultur na siebie. Im bardziej społeczeństwa zaczynają od siebie zależeć, tym mniejsze są możliwości odseparowania się kulturowego, mimo występowania zjawiska gettoizacji, zamykania granic, embarga itd. W takich przypadkach następuje wymuszanie przyjęcia określonego, wąskiego zestawu reguł, czemu towarzyszy utrata indywidualności przez jednostki. Erich Fromm ujmował ten proces w kontekście zastępowania wolności pozytywnej („wolności do”) wolnością negatywną („wolnością od”)

\section{Cykliczność innowacyjności}

Konkurowanie ze sobą społeczeństw wymusza przyjmowanie innowacji, szczególnie technicznych, dzięki czemu utrzymywany jest stan dynamicznej równowagi. Brak zewnętrznego zagrożenia prowadzi do niechęci wobec przyjmowania

33 Merton ujmował anomię nie tylko w kontekście innowacji, ale także innych dewiacji związanych z omijaniem reguł kulturowych, tj. rytualizmu, wycofania i buntu. Dewiacje te opisywał przede wszystkim jako reakcję na stan anomii: R.K. Merton, Teoria socjologiczna i struktura spoteczna, przeł. E. Morawska i J. Wertenstein-Żuławski, Warszawa 2002, s. 239-252.

$34 \quad$ F. de Waal, Bonobo i ateista, przeł. K. Kornas, Kraków 2016.

35 E. Fromm, Ucieczka od wolności, przeł. O. i A. Ziemilscy, Warszawa 2001. 
innowacji, a dalekosiężnym skutkiem tego może być upadek cywilizacyjny ${ }^{36}$. Równorzędnym lub prawie równorzędnym partnerom łatwiej jest prowadzić grę o sumie niezerowej, czego rezultatem jest rozwój społeczny. W perspektywie makrospołecznej korzystną dla populacji jest wymiana kulturowa, ale jeśli postępujące zmiany są zbyt uciążliwe dla jednostek, co prowadzi do mechanizmów separowania się od zewnętrznych wpływów, okresy wzrostu kulturowej różnorodności przeplatane są okresami radykalnego izolacjonizmu. Czynnikami inicjującymi takie izolowanie się mogą być sytuacje realnego zagrożenia lub też wyobrażeń o zagrożeniu. Patrząc na zmiany zachodzące w ostatnich dwóch stuleciach, można zauważyć, że kryzysy ekonomiczne generujące zagrożenie egzystencji dla ludzi zależnych od pieniądza (co wyróżnia społeczeństwa mające już za sobą wejście w erę industrialną) prowadzą do gwałtownych reakcji. Sutkiem głębokiego kryzysu jest II wojna światowa, ale przede wszystkim wcześniejsza izolacja europejskich społeczeństw i upowszechnianie się autorytaryzmów. Kryzys końca lat 70. XX wieku idzie w parze z eskalacją wyścigu zbrojeń między blokiem wschodnim i zachodnim oraz uszczelnianiem „żelaznej kurtyny”. Odradzające się współcześnie tendencje separatystyczne (pomysł na budowę wielkiego muru w USA i podobne odgradzanie się od migrantów w Europie) pojawiają się też niedługo po głębokim kryzysie ekonomicznym ${ }^{37}$.

Opisywane cykle zmian koniunkturalnych oraz towarzyszących im kryzysów wydają się zachodzić w miarę regularnie, natomiast tempo innowacji staje się coraz większe. Trudno byłoby więc powiedzieć, że większe natężenie innowacji prowadzi do reakcji i izolacjonizmu. Być może jednak liczba innowacji istotnych dla społecznego i kulturowego funkcjonowania nie jest aż tak duża lub prowadzi do swoistej habituacji. Kolejne gorące newsy i pozwalające nam „lepiej żyć” gadżety przestaja na nas oddziaływać. Niemniej efektem tej „habituacji” może być zamykanie się na wpływy, co w cyberprzestrzeni określa się mianem funkcjonowania w „bańkach medialnych”. Nie oznacza to jednak, że żyje się w zupełnie izolowanych światach kulturowych. Alternatywne idee mogą być odrzucane na poziomie świadomym, ale mimo to być propagowanymi. Włączanie obcych memów może zachodzić w sposób kontrolowany. Kontrolowanie oznacza tu nie tyle racjonalne działanie, ile odpowiednie reagowanie sieci memów (mempleksów) na nowe memy. Tak jak $\mathrm{w}$ procesie resocjalizacji zachodzi alternacja polegająca na całkowitym przewartościowaniu subiektywnego rozumienia otaczającej rzeczywistości dla jednostki

36 Robert Wright przywołuje cywilizację rzymską oraz chińską, obie podbite przez plemiona znajdujące się na znacznie niższym poziomie rozwoju: R. Wright, Nonzero. Logika ludzkiego przeznaczenia, przeł. Z. Łomnicka, Warszawa 2005.

37 Chociaż cykliczność kryzysów ekonomicznych opisywano już na początku XX wieku, nadal trudno określić, jaka jest ich długość, jakie są czynniki je wywołujące, a przez to trudno przewidywać przyszłe zmiany w dynamice wzrostu gospodarczego. Patrz A.V. Korotayev, S.V. Tsirel, A Spectral Analysis of World GDP Dynamics: Kondratieff Waves, Kuznets Swings, Juglar and Kitchin Cycles in Global Economic Development, and the 2008-2009 Economic Crisis, "Structure and Dynamics" 2010, nr 4(1). 
wchodzącej (lub powracającej) do danej zbiorowości ${ }^{38}$, tak włączanie memów z alternatywnych baniek oznacza zmianę ich funkcji/znaczenia w nowym mempleksie. Przykładem są różne formy synkretyzmu sprzyjające narzucaniu ideologii przez kulturę dominującą. Argumenty przeciwników mogą być potraktowane jako grunt dla wzmocnienia własnych idei poprzez nadanie im negatywnych konotacji. Tym samym memy generujące takie idee przestają być replikatorami czynnymi ${ }^{39}$, a więc wpływającymi na swoje własne propagowanie. Włączany do mempleksu mem, który mobilizuje do działania jedną grupę, może służyć jako etykieta tej grupy w innej zbiorowości, ale nie oddziaływać na jej zachowania.

Analizując bańki medialne jako mempleksy (a także inne formy kulturowego zamykania się na wpływy), należałoby założyć, że im silniejsza będzie polaryzacja, tym silniejsze będą sankcje związane z odstępstwami od reguł, wyraźniejsza instytucjonalizacja działań oraz wyraźniejszy mechanizm wąskiego gardła w postaci np. kultywowania rytuałów przejścia bądź formalizacji komunikacji. Z kolei im bardziej odczuwane jest zagrożenie, tym bardziej prawdopodobne jest tworzenie koalicji między „bańkami” zawierającymi podobne zestawy memów. Może mieć to przełożenie na kwestie ekonomiczne. Od końca XX wieku obserwuje się stopniowe fuzje firm związanych z biznesem medialnym. Jak zauważył Manuel Castells, o ile w 1983 roku identyfikowano 50 firm kontrolujących amerykański rynek medialny, to w roku 2004 było już ich 10 razy mniej ${ }^{40}$. W tym samym czasie rozwijała się przestrzeń internetu traktowana jako zagrożenie dla tradycyjnego biznesu.

\section{Globalne ocieplenie jako zagrożenie i potencjalny katalizator kulturowej polaryzacji}

Współczesnym zagrożeniem dla gatunku Homo sapiens są zmiany zachodzące pod wpływem globalnego ocieplenia, które zresztą przez ludzi zostało zainicjowane. Ponieważ zachodzi ono nierównomiernie w skali globu, a apele o redukcję dwutlenku węgla (traktowanego jako gaz cieplarniany) ze strony klimatologów wiążą się z ograniczeniem używania paliw kopalnych, budzi to opory ze strony części podmiotów gospodarczych i politycznych, jak również polaryzuje relacje między zainteresowanymi problemem obywatelami wielu państw. Dodatkowo prognozuje się gwałtowniejszy wzrost temperatur oraz katastrofalnych skutków dla biosfery w kolejnych dekadach bieżącego stulecia. Paradoksalnie może to generować myślenie, że jest to problem, którym należy zająć się w przyszłości. Chociaż zagrożenie dla ludzkich populacji jest postrzegane wyraźnie przez jedną stronę

38 Por. P.L. Berger, Th. Luckmann, Spoteczne tworzenie rzeczywistości, przeł. J. Niżnik, Warszawa 2010.

39 Podział replikatorów na czynne i bierne (a także na generatywne i ślepej uliczki, których przykładami są gamety i komórki somatyczne) zaproponował Richard Dawkins. Jako istotne dla procesów ewolucji uznał czynne replikatory generatywne. Zob. R. Dawkins, Fenotyp rozszerzony, przeł. J. Gliwicz, Warszawa 2003, s. 114-115.

$40 \quad$ M. Castells, Wtadza komunikacji..., s. 85. 
sporu, to jednak druga, jeśli styka się z argumentami trudnymi do obalenia, może trywializować zagrożenie, albo też reagować brakiem zaufania. Tak zwani sceptycy klimatyczni mogą negować komunikaty o globalnym ociepleniu nie dlatego, że się z nimi nie zgadzają, lecz ze względu na to, że w sytuacji poczucia zagrożenia mogą tracić zaufanie do autorów przekazu. Negatywne emocje mogą bowiem prowadzić do spadku zaufania ${ }^{41}$. Aby przekonywać zwolenników własnej opcji, strony sporu w różny sposób próbują włączać argumenty przeciwników do własnej narracji (do własnego mempleksu). Na podstawie kilkuletniej obserwacji komentarzy zamieszczanych w trzech serwisach internetowych, autor niniejszego artykułu podjął próbę określenia, w jaki sposób memy zagrożenia, sceptycyzmu i demaskacji oszustów ${ }^{42}$ przenikają do „wrogich” mempleksów w sytuacji polaryzacji sporu o globalne ocieplenie. Analizowanymi serwisami były: strona naukaoklimacie.pl prowadzona przez polskich popularyzatorów wiedzy o zachodzących zmianach klimatycznych, blog arcticicesea.blogspot.com prowadzony przez jednego z autorów powyższego serwisu, a dotyczący sytuacji roztapiającego się lodu arktycznego oraz anglojęzyczne forum internetowe forum.arctic-sea-ice.net podejmującego kwestie znikania lodu głównie w Arktyce, ale też w całej kriosferze Ziemi.

Dyskusje zarówno na forum, jak i w pozostałych dwóch serwisach wyraźnie angażują uczestników. Rzadko pojawiają się osoby, które po wypowiedzeniu się przestają uczestniczyć w dyskusji. W serwisie naukaoklimacie.pl oraz na blogu komentarze moga pojawiać się jedynie pod zamieszczanymi artykułami, więc przewagę w propagowaniu informacji mają osoby prowadzące te strony. Na forum internetowym jednak także zaangażowani użytkownicy prowadzą własne serwisy zawierające m.in. wykresy ilustrujące zmiany, które następnie są komentowane. Dwa z nich są wyeksponowane w nagłówku forum ${ }^{43}$. Obie strony prezentowanego sporu wykorzystują informacje przedstawiane przez przeciwników, jednak to autorzy treści o zmianach klimatycznych są bardziej zdeterminowani do formułowania podsumowań, a także do zawierania autorefleksji na temat samego przekazu informacji. Przykładowo „klimatyczni sceptycy” wobec komunikatów przedstawiających zagrożenie dla biosfery argumentują, że ograniczenia dla przemysłu skutkować będą zagrożeniem dla gospodarki, co prowadzi do odpowiedzi ze strony klimatologów, że również gospodarka będzie zagrożona w przypadku postępującego ocieplenia ze względu na mniejszą wydajność pracowników w nowych warunkach klimatycznych. Szybko jednak wymiana argumentów zmierza w stronę zarzutów dotyczących wspierania lobbujących grup interesów. Z jednej strony pojawiają się komunikaty o manipulowaniu danymi przez biznes paliwowy

41 A. Ciążela, Ztość ufności szkodzi, „Świat Nauki” 2019, nr 5.

42 W ujęciu Richarda Brodiego są to memy odnoszące się do wykrywania niebezpieczeństw i przetrwania jednostki. Zob R. Brodie, Wirus umystu, przeł. P. Turski, Łódź 1997, s. 115-126.

43 Jest to blog jednego $\mathrm{z}$ najaktywniejszych użytkowników: neven1.typepad.com oraz zestaw wykresów dotyczących zmian zachodzących w kriosferze: sites.google.com/site/ arcticseaicegraphs. 
i tworzone przez niego instytucje, z drugiej podkreślanie tego, że popularyzatorzy wiedzy o klimacie wspierani są przez organizacje, które wcześniej także były związane z tym biznesem. Orężem w tym konflikcie bywa także wskazywanie myślenia spiskowego. Jest to sytuacja nieco odmienna od innego sporu związanego z zagrożeniem dla życia człowieka, mianowicie między zwolennikami i przeciwnikami stosowania szczepionek, gdzie kwestia myślenia spiskowego przypisywana jest tylko antyszczepionkowcom ${ }^{44}$.

Antagonizmy wzmacniane sa przez traktowanie oponenta jako niekompetentnego oraz przez ignorowanie przedstawianych informacji. W pierwszym przypadku jest to m.in. zakładanie niezrozumienia mechanizmów prowadzących do opisywanych zjawisk, co pozwala na określenie klimatycznego „negacjonisty” jako niepojmującego zagadnień, które krytykuje. Zabiegiem erystycznym kierowanym przeciwko popularyzatorom wiedzy o klimacie jest określanie ich jako „wierzących” w globalne ocieplenie, co ma być przeciwieństwem postawy naukowego sceptyka. Odnoszenie się do wiary lub negacji skutkuje z kolei odchodzeniem od merytorycznej dyskusji w stronę etykietowania przeciwnika. Ponieważ towarzyszy temu ignorowanie merytorycznej części informacji zawieranych we wpisach, debata częściowo zmienia się w dialog głuchych. Nierzadko internauci reprezentujący klimatycznych sceptyków używają argumentu, że nawet jeśli przyjąć, iż za globalne ocieplenie odpowiada człowiek, to dzięki rozwojowi technologicznemu da się znaleźć rozwiązania pozwalające na ograniczenie negatywnych konsekwencji tego zjawiska. Późniejsze przywoływanie przez inne osoby problemu opracowania technologii służących radzeniu sobie ze zmianami klimatycznymi bywa traktowane jako próby forsowania obejścia problemu redukcji $\mathrm{CO}_{2}$. Eksperci od klimatu rzadko bywaja inżynierami, więc również stąd skłonność do unikania przez nich tej tematyki.

Kontrargumentowanie jest strategią, która pozwala na oswojenie treści przeciwników, co w perspektywie memetycznej można rozumieć jako podporządkowanie „wrogich” memów przez kluczowe memy (meta-memy) własnego mempleksu. W przypadku serwisu naukaoklimacie.pl służy temu zbiór artykułów skategoryzowanych (otagowanych) jako „fakty i mity”, zawierających odpowiedzi na wysuwane argumenty przez różne osoby mogące wpływać na opinię publiczną - od polityków, przez dziennikarzy po naukowców. Corocznie serwis ten przyznaje antynagrodę, „Klimatyczną bzdurę roku”, a przygotowany wcześniej zestaw mitów jest wykorzystywany do prezentacji kandydatur do tejże antynagrody. Wobec argumentu o braku spójnego stanowiska w środowisku naukowym w kwestii antropogenicznego ocieplenia przywołuje się kontrargument o tym, że żadna renomowana organizacja naukowa nie zaprzecza wpływowi człowieka na klimat. Jest to argument odnoszący się do autorytetu, a nie do wiedzy, co

$44 \quad$ Szersza analiza memetycznej wojny między zwolennikami i przeciwnikami szczepionek została przedstawiona w pracy: M. Mrowiec, „Pamiętasz, jak miateś polio?...”. O szczepionkowych wojnach memów w perspektywie dtugiego trwania, „Teksty z Ulicy. Zeszyt memetyczny” 2016, nr 15. 
jest skutkiem podjęcia dyskusji na polu pozamerytorycznym ${ }^{45}$. Niemniej wśród pretendentów do wymienionej wyżej antynagrody za rok 2018 znalazł się również klimatolog. Innym sposobem oswajania jest prezentowanie wiedzy o zmianach w sposobie myślenia wśród przeciwników zmian klimatycznych. Przedstawia się w tym przypadku ewolucję myślenia ukazującą mechanizm zaprzeczania - od zakładania, że globalne ocieplenie nie istnieje, po stwierdzenie, że jest już zbyt późno, aby jakiekolwiek zmiany w podejściu do spalania paliw kopalnych mogły ograniczyć negatywne skutki działalności człowieka. Teksty artykułów formułowane są zresztą w taki sposób, że już w nich samych pojawiają się odpowiedzi na potencjalne ataki. Jednocześnie występuje przy tym etykietowanie. W tekstach uwidaczniają się też mechanizmy projekcji. Mem zagłady (,już nic nie da się zrobić”) przypisywany denialistom (sceptykom klimatycznym) współwystępuje z oczekiwaniami, że nastąpią negatywne zjawiska potwierdzające prognozy klimatologów. Na forum internetowym forum.arctic-sea-ice.net emotikony wyrażające przerażanie wobec bieżących zmian w kriosferze Ziemi pojawiają się obok ikon wyrażających rozbawienie (radość). Jego uczestnicy kilka razy do roku organizuja głosowania, w których próbują oszacować krzywą topnienia lodu w Arktyce oraz osiągane minima. Użytkownicy okazujący zbytni entuzjazm wobec postępującego ocieplania są strofowani przez innych internautów, którym takie emocje również zdarza się okazywać. Wobec memów wyzwalających emocje polaryzujące się bański medialne nie mają utworzonego odpowiedniego „systemu immunologicznego”. $\mathrm{Na}$ blogu arcticicesea.blogspot.com nierzadko pojawiają się tytuły angażujące emocjonalnie czytelnika, przypominające formą nagłówki tabloidów („Arktyczny zmierzch cywilizacji”, „Ognie piekielne w Rosji i metan”, „Katastrofa klimatyczna w Arktyce - nie ma już szans”, „Plaga arktycznych upałów powraca”).

Rozpatrując kwestię towarzyszącego sporowi etykietowania, zauważono, że popularyzatorów wiedzy o klimacie (klimatologów bądź sprzyjających im komentatorów) określa się jako: propagandystów, fundamentalistów, katastrofistów, a także jako komunistów, użytecznych idiotów i ekoterrorystów. Przeciwników zmian klimatycznych etykietuje się natomiast jako: piszących bzdury, nieuków, promujących teorie spiskowe, opłacanych trolli internetowych, niereformowalnych osobników bądź jako osoby myślące życzeniowo. Zazwyczaj inwektywy nie są kierowane bezpośrednio wobec dyskutantów, lecz podawane jako dodatki do własnej wypowiedzi, co może sugerować mniej lub bardziej pogardliwą relację. W łatwy sposób przychodzi też wpychanie przeciwników w dominujące bański medialne. Wskazywanie działań polityków i reprezentantów biznesu jako problemu dla propagowania wiedzy o klimacie prowadzi do wytworzenia polaryzacji między decydentami a prowadzącymi badania klimatologami. „Biznes jak zwykle” to

45 Argument ten z infografiką ukazującą wiele organizacji naukowych potwierdzających istnienie globalnego ocieplenia wobec braku żadnej, która by temu zaprzeczała, znalazł się w rozdziale wprowadzającym książki przygotowanej przez zespół prowadzący ten serwis: M. Popkiewicz, A. Kardaś, S. Malinowski, Nauka o klimacie, Warszawa 2019. 
hasło określające brak działań ze strony gospodarek na rzecz redukowania dwutlenku węgla i często występuje w prognozach przyszłych zmian klimatycznych. Ta awersja do środowisk przedsiębiorców wzmacniana jest przez swoistą mimikrę kulturową. Klimatolodzy co jakiś czas informują o organizacjach prowadzonych przez osoby powiązane z przemysłem paliwowym, których nazwy kojarzyć mają się z badaniami klimatu. Podmioty te zajmują się natomiast rozsyłaniem komunikatów wspierających tezy denialistów. Wyraźne jest też (nie tylko w etykietach) przypisywanie klimatologom światopoglądu lewicowego, a sceptykom prawicowego.

Opisane powyżej dwa przeciwstawne obozy, ale również dwa polaryzujące się mempleksy (narracje) stosują odmienne strategie rozpowszechniania informacji. Strategia popularyzatorów polega na przedstawianiu skumulowanej wiedzy, popartej wieloma odnośnikami do artykułów naukowych. Aby móc wyjaśnić złożone zjawiska, koniecznym jest częste odnoszenie się do wielu publikacji, w tym wcześniej tworzonych na własnych stronach komunikatów (także wpisów na blogu i komentarzy na forum). Strategia klimatycznych sceptyków polega na wyłapywaniu błędów, głównie sprzeczności, w stanowiskach klimatologów, a następnie masowe powielanie informacji o takich błędach. Zgodnie z modelem wirusowym, najszybciej replikującymi się memami mogą być memy odnoszące się do tych aspektów życia człowieka, które są istotnymi w kontekście jego biologicznej ewolucji, a zarazem będące krótkimi informacjami, mocno angażującymi umysły oraz skłaniające jednostki do ich powielania. Za Brodiem można powiedzieć, że są to memy drażniące czułe punkty, w tym przypadku takie, które mają ukazywać popularyzatorów wiedzy o zmianach klimatycznych jako zagrażających dobrobytowi, a więc zagrażających łatwemu dostępowi do zasobów ${ }^{46}$, a jednocześnie jako manipulujących danymi oszustów wspieranych z publicznych funduszy. Jeśli dany mem wprowadzony przez denialistów dobrze się replikuje, koniecznym staje się dementowanie, a więc przeznaczanie dużej ilości czasu na kolejne wyjaśnienia, czasami przyznawanie, że dana wypowiedź była skrótem myślowym, mogącym prowadzić do wyciągania błędnych wniosków u odbiorców. Im częstsze są jednak ataki takimi wirusami memetycznymi, tym trudniej reagować długimi wypowiedziami, pozwalającymi na wytłumaczenie złożoności opisywanego problemu. W rezultacie prowadzi to nierzadko do frustracji u klimatologów, reagowania emocjonalnego, a więc przyjmowania memów wyzwalających etykietowanie przeciwników, sprzyjających narracji o prostym (niezłożonym) świecie. Często jednak to nie przedstawiciele środowiska naukowego, ale życzliwi im (czasem mniej lub bardziej zapoznani z problematyką globalnego ocieplenia) komentatorzy produkują etykiety wobec przeciwników, podsycając spór. Z kolei brak instytucji społecznego moderatora (poza wymienionym forum internetowym) powoduje, że znaczna część czasu przeznaczona na prowadzenie serwisu przenoszona jest na odpowiadanie kolejnym użytkownikom. Zazwyczaj ma to także formę szablonowych wypowiedzi z odsyłaniem do wcześniej publikowanych artykułów.

$46 \quad$ Por. R. Brodie, Wirus..., s. 84. 
W przypadku obu środowisk można mówić o dwóch rodzajach memów regulatorowych: skupiających uwagę odbiorców 1) na zagrożeniu oraz 2) na możliwych fałszerstwach. Im wyraźniej klimatolodzy wskazują na zagrożenia wynikające $\mathrm{z}$ antropogenicznego ocieplania klimatu, a także fake newsy produkowane przez podszywające się pod badaczy klimatu organizacje, tym bardziej sceptycy koncentrują się na wskazywaniu oszustw związanych z badaniami nad klimatem oraz zagrożeniami, jakie niesie dla gospodarki ograniczanie opartego na węglu przemysłu. Niewykluczone, że przy dalszym wzroście zagrożenia proces ten będzie się nasilał, a wojna informacyjna wykorzystująca różne strategie „informowania o zagrożeniu” i „demaskowania oszustów” będzie prowadzić do wytwarzania coraz skuteczniejszych memów w obu obozach. Skutkiem tego może być przyspieszająca polaryzacja, szczególnie jeśli więcej osób zacznie odczuwać skutki zagrożeń.

\section{Uwagi końcowe}

Zbiorowości funkcjonujące w erze przed pojawieniem się internetu, a tym samym tworzone przez nie mempleksy, mogły być w miarę łatwo izolowane geograficznie. Przenikanie nowych memów wiązało się z migracjami, ale też z terytorialną agresją. Mempleksy utrwalały się w obrębie państw narodowych i grup religijnych, wcześniej też wewnątrz murów miejskich, dopóki miasta miały dużą autonomię. Globalna sieć internetu wymusiła nowe formy konfigurowania sieci społecznych. O ile w danym państwie kontrola internetu nie jest duża, o tyle jednostki maja większą swobodę w tworzeniu własnych sieci społecznych. Funkcjonowanie w obrębie danego mempleksu można tu traktować jako wypadkową ekspozycji na dany rodzaj mediów i zawartych w nich treści. Dobór takich treści przez jednostkę jest z kolei skutkiem oddziaływania osób w jej otoczeniu fizycznym i przypadkowych odwiedzin poszczególnych portali internetowych. Im efektywniejsze są memy wytwarzane w danym miejscu cyberprzestrzeni, tym większe prawdopodobieństwo, że stykające się z nim jednostki będą wytwarzać silną wspólnotę.

Prezentowanie powoli zachodzących procesów nie jest na pewno czymś, co łatwo może przyciągać publiczność. Dlatego też w komunikatach dotyczących zmian klimatycznych przedstawia się spektakularne wydarzenia będące efektem klimatycznej antropopresji. Stąd ilustrowanie wiadomości wykresami, które ukazują zmiany w długiej perspektywie czasu, jest ukazywaniem ostatnich dziesięcioleci jako momentu w skali geologicznej. Takie porównania pozwalają na łatwiejsze zrozumienie gwałtowności zmian klimatycznych. Przyjęcie perspektywy ujmowania bieżących zmian jako nagłych wymaga jednak przemodelowania własnego myślenia o otaczającej rzeczywistości. Popularyzatorzy prezentujący kolejne komunikaty o zachodzących zmianach, ujmujący je w dłuższej skali, zazwyczaj ilustrują je wieloma różnorodnymi wykresami. Już sam ten zabieg wymaga oswojenia się z interfejsem oraz myślenia kategoriami relacji w krótkiej i długiej skali. To jednak może wystąpić u osób zainfekowanych wcześniej memem globalnego ocieplenia. 
Aby trafić do niezaznajomionych, skuteczniejsze jest oddziaływanie na emocje. Zbyt emocjonalne komunikowanie bywa jednak przeciwskuteczne, ponieważ często prowadzi do spadku zaufania i wzrostu sceptycyzmu wobec prezentowanych treści.

\section{BibLIOGRAFIA}

Berger P.L., Luckmann Th., Spoteczne tworzenie rzeczywistości, przeł. J. Niżnik, Warszawa 2010. Borkowski W., Memy - reinterpretacja systemowa, „Teksty z Ulicy. Zeszyt Memetyczny” 2016, nr 17. Brodie R., Wirus umystu, przeł. P. Turski, Łódź 1997.

Castells M., Wtadza komunikacji, przeł. J. Jedliński, P. Tomanek, Warszawa 2013.

Celiński P., Interfejsy. Cyfrowe technologie w komunikowaniu, Wrocław 2010.

Ciążela A., Ztość ufności szkodzi, „Świat Nauki” 2019, nr 5.

Coveney P., Highfield R., Granice ztożoności, przeł. P. Amsterdamski, Warszawa 1997.

Danel D., Pawłowski B., Biologiczne znaczenie atrakcyjności twarzy, W: Biologia atrakcyjności człowieka, red. B. Pawłowski, Warszawa 2009, s. 174-175.

Dawkins R., Fenotyp rozszerzony, przeł. J. Gliwicz, Warszawa 2003.

Dennett D., Od bakterii do Bacha. O ewolucji umystów, przeł. K. Bielecka i M. Miłkowski, Kraków 2017.

Dunbar R., Człowiek. Biografia, przeł. Ł. Lamża, Kraków 2016.

Dunbar R., Pchty, plotki, a ewolucja jezyka, przeł. T. Pańkowski, Kraków 2017.

Fromm E., Ucieczka od wolności, przeł. O. i A. Ziemilscy, Warszawa 2001.

Gamble C., Gowlett J., Dunbar R., Potega mózgu. Jak ewolucja życia spotecznego ksztattowała ludzki umyst, przeł. R. Kosarzycki, Kraków 2017, s. 54-56.

Korotayev, A.V., Tsirel S.V., A Spectral Analysis of World GDP Dynamics: Kondratieff Waves, Kuznets Swings, Juglar and Kitchin Cycles in Global Economic Development, and the 2008-2009 Economic Crisis, „Structure and Dynamics” 2010, nr 4(1).

Leach E., Kultura i komunikowanie, przeł. M. Buchowski, Warszawa 2010.

Lévi-Strauss C., Antropologia strukturalna, przeł. K. Pomian, Warszawa 2000.

Łaszczyca P., Memy w pamięci: jak wyśledzić memy z mózgu, „Teksty z Ulicy. Zeszyt Memetyczny” 2017, nr 18, s. 19.

Merton R.K., Teoria socjologiczna i struktura spoteczna, przeł. E. Morawska i J. Wertenstein-Żuławski, Warszawa 2002.

Mrowiec M., „Pamiętasz, jak miateś polio?...”. O szczepionkowych wojnach memów w perspektywie dtugiego trwania, „Teksty z Ulicy. Zeszyt memetyczny” 2016, nr 15.

Popkiewicz M., Kardaś A., Malinowski S., Nauka o klimacie, Warszawa 2019.

Ramachandran V.S., Neronauka o podstawach człowieczeństwa, przeł. A. i M Binderowie, E, Józefowicz, Warszawa 2012.

Sout D., Neurobiologia epoki kamienia, „Świat Nauki” 2016, nr 5.

Stewart I, Cohen J, Wytwory rzeczywistości. Ewolucja umystu ciekawego, przeł. W. Stępień-Rudzka, Warszawa 2003.

Szlendak T., Kozłowski T., Naga matpa przed telewizorem. Popkultura w świetle psychologii ewolucyjnej, Warszawa 2008.

Tsao D.Y., Kod twarzy, „Świat Nauki” 2019, nr 3.

Waal F. de, Bonobo i ateista, przeł. K. Kornas, Kraków 2016. 
Watson J. D., Podwójna helisa, przeł. W. Zagórski, Warszawa 1996.

Wilson E.O., Konsiliencja. Jedność wiedzy, przeł. J. Mikos, Poznań 2002.

Wright R., Nonzero. Logika ludzkiego przeznaczenia, przeł. Z. Łomnicka, Warszawa 2005.

Zimmer C., Sto bilionów potaczeń, „Świat Nauki” 2011, nr 2.

\section{Nota o autorze}

Sebastian Skolik - doktor nauk humanistycznych, socjolog, adiunkt w Zakładzie Socjologii Zarządzania Politechniki Częstochowskiej. Zajmuje się zagadnieniami dotyczącymi projektów wolnej kultury, procesami instytucjonalizacji w przestrzeni społecznej Internetu, relacjami społecznymi w projektach Fundacji Wikimedia, kapitałem społecznym i ewolucją zachowań prosumpcyjnych.

\section{About the author}

Sebastian Skolik - an assistant professor at the Technical University of Częstochowa. His research interests focus on free culture movement, open collaboration projects and institutionalization processes in online social spaces. His recent publications focus on the evolution of prosumption, intellectual and social capital in online projects and interpersonal relationships in Wikimedia communities. 